International Journal of Business Management, Entrepreneurship and Innovation, Volume 3, Issue 1, 2021, PP 49-64, ISSN 2707-8027

[IJCAB

\title{
Customer Development Strategies and Performance of Start Up Carbon Projects; A Case of Study of Sustainable Agriculture Tanzania (SAT)
}

\author{
Betty Jeruto Cheruiyot ${ }^{1}$, Dr. Mary Ragui ${ }^{2}$ \\ ${ }^{1}$ Department of Business Administration, School of Business, Kenyatta University, Kenya \\ ${ }^{2}$ Lecturer, Department of Business Administration, School of Business, Kenyatta University, \\ Kenya
}

\begin{abstract}
\end{abstract}
Present challenges experienced by a globalized and changing world with new forms of doing business has forced entrepreneurs to change their approach to customers especially given the prior traditional marketing theory. Current markets have a customer base with increased demand for more marginal products or services; henceforth, they have created individual preferences. The general objective of this study was to establish the effect of customer development strategies on performance of start-up carbon projects; a case of study of sustainable agriculture Tanzania (SAT). Specifically, it aimed at examining the effect of business model on Performance of forest carbon projects, examining the effect of customer service systems on Performance of forest carbon projects, the effect of communication process on Performance of forest carbon projects, including effect of competitive pricing on Performance of forest carbon projects. It is anchored on theory of product market fit, start-up marketing pyramid and cue utilization theory. The study is further supported by the following models; business model canvas, value proposition canvas and customer development model. The study used a survey design. The survey collected data and information aimed at identifying customer development strategies for performance of carbon projects in the start-up carbon market. The selected population were customers of Sustainable Agriculture Tanzania. They consisted of companies, partners and individuals who were involved with the carbon offsetting project or potential clients. Ten companies and fifty individual customers were selected for the survey. Individual customers were drawn from the current connections developed by Sustainable Agriculture Tanzania. Primary and secondary data was utilized from various secondary sources linked to the topic of study and gathered facts and figures from the questionnaires. The questionnaire comprised of questions relating to the carbon markets for organizations in the start-up carbon projects. The quantitative data retrieved from the study was analysed by use of descriptive statistics that included variability, frequency and central tendency measures. These help provide information regarding the distribution. Measures of frequency distribution on the other hand document the frequency of scores or records. The Statistical Package for Social Sciences (SPSS) program was used to analyse the data and output presented in form of tables, pie charts and bar graphs. The study found out that customer development strategies in start-up forest carbon projects are central to performance of forest carbon projects. Playing a part to this performance are particularly the company's prices, enhanced innovation and creativity, business management systems, reduction of the time required for decision-making and improved planning of activities. At the same time, use of IT data management systems has to a large extent made decision-making process faster. These aspects generally lead to better management of budgets, efficiency in service provision, consistent increase in revenue and increased number of customers. Moreover, customer development strategies lead to customer satisfaction improvement. In conclusion to the presented findings, communication process and customer service systems have shown to influence the performance of forest carbon projects. Setting up a tailored business model that works well with the cost structure of the business and suits project goals has also been visibly altering the functioning of projects. The strategy implemented on pricing is also seen to promote customer growth. It is recommended that start-up projects develop relevant pricing strategies 
International Journal of Business Management, Entrepreneurship and Innovation, Volume 3, Issue 1, 2021, PP 49-64, ISSN 2707-8027

iJCAB

for their products; especially during their early stages of development in order to differentiate and grow a viable customer base. Managers should also encourage proper training and practices when it comes to inter-organizational communication and strategy implementation. This will ensure every employee works in cohesion towards achieving the projected goals thus improving performance.

Key Words: Customer Development Strategies, business model, customer service systems, communication process, competitive pricing strategies, Start Up Carbon Projects, Sustainable Agriculture Tanzania (SAT)

DOI: $10.35942 /$ jbmed.v3i1.164

\section{Cite this Article:}

Cheruiyot, B., \& Ragui, M. (2021). Customer Development Strategies and Performance of Start Up Carbon Projects; A Case of Study of Sustainable Agriculture Tanzania (SAT). International Journal of Business Management, Entrepreneurship, and Innovation, 3(1), 49-64. https://doi.org/10.35942/jbmed.v3i1.164

\section{Introduction}

Numerous causes for the decline of start-ups outlast their actual numbers Ries (2008). Founders many a time cherish their ideas a great deal that they overrule validating their beliefs in practicality, or disregard details that contrast to their idea of the customer needs Blank (2005). Due to this, there is a risk of wasting resources on what does not appeal to the market (Blank \& Dorf, 2012). The Lean Start-up Methodology literature aims to challenge this through increased customer input right from the start of product development. The concept of Customer Discovery is included in Lean Start-up Methodology as acquiring customer feedback and revising business concepts early in the developmental stages. In most cases, a mission conceptualized by inclusion of a strategy moves a company. That is; how the company acquires input on the market so as to cater to the needs of the market, which is normally tackled through a built portfolio of the product adjusted constantly as per generated revenue streams.

Conversely, a start-up does not pose as an established and operating organization. They are ventures that deal with transformations. There is still work towards institutionalization of functional structures and processes. Also, focus is directed towards a developed market segment with an attractive product Blank (2012). Many young establishments stagnate (Mullins \& Komisar 2009, Crowne 2002) because of wasting resources creating an insatiable product. Only about $2 \%$ of brand-new ideas survive, meaning the rest lack to flourish as they exclude a procedure for examining the set frameworks (Blank \& Dorf, 2012). In return, it brings about insufficient resources and a lack of product and financial feasibility testing. Realizing that it is incumbent to respond, organizations rapidly switched older product responsive approaches and focused more on developing their customers (Blank \& Dorf, 2012). Regimented operations focus on building products efficiently, these methods may offer product-based solutions but lack a focus on what is required by the market (Bosch et al., 2013). The dilemma on what customers require arises when start-ups fail to find solutions on customer needs, this is immediately associated with absence of focus on customer centric solutions earlier on in the business. (Eisenmann, Ries, \& Dillard 2012). In regard, many companies have embraced the Lean Start-up Methodology (LSM) as it is found to be a wholly procedure to tackling numerous variabilities linked to start-ups. (Harb, Noteboom, \& Sarnikar 2015). The methodology is clear on cutting losses and building value for customers, done right from the inception of a company Blank (2013). Lean start-up is a construct used to develop ventures and their products in order to minimalize the cycle of product development and develop a viable business model. 
International Journal of Business Management, Entrepreneurship and Innovation, Volume 3, Issue 1, 2021, PP 49-64, ISSN 2707-8027

IJCAB

Sustainable Agriculture Tanzania (SAT) is a non-governmental organization based in Morogoro, Tanzania. Established in 2011, its aim is to address the social and environmental problems linked to unsustainable agricultural practices in Tanzania. The result of these untenable uses of land has often led to land degradation, pollution, climate change, wasteful water use, land conversion and habitat loss. Continued use of such unsustainable practices threatens the environmental sustainability with reduction of function within ecosystems and ultimately, undermining nutritional and health value of food. One of the approaches that SAT has taken in promoting environmental sustainability has been the introduction of its projectFairCarbon4Us. SAT initiated FairCarbon4Us in 2016, a carbon sequestration scheme that involves small-scale farmers in the planting of trees. So far, 100 farmers have been enrolled through this initiative, with more than 8,900 trees being planted. Still a start-up, SAT's future plans are to broaden its activities further into reforestation, afforestation and forest protection through the help of such farmers. The solutions provided under FairCarbon4Us are in form of three projects which include; Food Forest, Agroforestry and Bio char and Spicy Carbon.

The Food Forest Project involves the planting of fruit trees and other types of trees in sections that are not utilized for farming. The farmers are divided into groups and presented with trees from the established tree nurseries organized by SAT. During the period of tree planting and management, the farmers receive payments that last over a period of 5-8 years. Their progress during the project is monitored by the farmer group and validated by SAT team and depending on their performance, they are equally rewarded. Agroforestry involves planting of trees or shrubs alongside, around and among crops or pasture. The Agroforestry and Bio char Project to be initiated by SAT will include dispersed intercropping and boundary planting. The intercropping system will provide biomass from pruning, which will be utilized in the production of bio briquettes to offer an alternative for managing deforestation. The other initiative under FairCarbon4Us is The Spicy Carbon Project, a project that deals with spice producers in the Uluguru Mountains to help reduce deforestation and promote reforestation practices. The farmers will help protect the mountain slopes from erosion and at the same time practice reforestation.

\section{Statement of the Problem}

Current research relevant to customer development strategies indicates a positive impact on the potential of its application to the corporate environment. Developed by Silicon Valley entrepreneurs, it has indicated the ability to withstand other business development applications mainly due to the flexibility of its processes and testing. The problem however comes to play in the way companies approach the process; principally in trying to categorize all the possible variables at play making the process lag on and crippling the capacity to make a timely move. Poor knowledge on the unique product offering is still a problem for performance of start-ups. Securing relations with resource providers such as customers, employees and suppliers also represents a crucial problem (Bhide, 2000). Given the perspective of resource providers, it indicates a greater risk with dealing with new firms as opposed to established companies. This is due to the factors in the macro environment such as; inflation, spending, technological changes and social conditions. Start-ups can be able to reduce these risks by being adaptive, flexible and alert to opportunity.

A deeper understanding on customer development strategy is required by both management and employees of start-up projects; this will enable them to concentrate on information relevant to the company's goals and enable them to test those ideas in the market. The knowledge gap and lack of information caused by cognitive bias means ventures need to listen more to customers and gain more input on how to stay relevant. This is necessary for creating systems that assist organizations in forecasting their short-term, current and long-term strategies when it comes to 
International Journal of Business Management, Entrepreneurship and Innovation, Volume 3, Issue 1, 2021, PP 49-64, ISSN 2707-8027

iJCAB

building and developing customers for start-ups. In his book, Steve Blank (2003) translates customer development into four major stages; the first entails finding out if there are any problems connected to the product. What follows is finding out what customers are willing to pay for it and finally the organization begins to increase production and construct the business. All these processes need reliable communication networks, feasible business models, relevant customer service and pricing. In the research, focus is on knowing more about how these variables influence the performance of carbon start-up projects.

Early streams of research investigate the building blocks of business models and the correlation of its various aspects, (Demil \& Lecocq, 2010; Teece, 2010; Zott et al., 2011). Researchers have also corroborated change of business models to assure growth and relevance amongst incumbent firms, (Chesbrough, 2007; Santos et al., 2009). This was established through an analysis of successful examples of innovative models. A good example of customer development is in retail markets; Tesco's launch of its club card has been exerted to keep customers and grow Tesco's value. Similarly, Kenyan retail chain Tuskys has its reward card that enables customers to gain points and get rewarded for how frequently they shop at Tuskys. Another strategy for customer development is how mobile networks create flexibility in pricing network services e.g. bundles. They also supplement this by using innovative approaches by penetrating the consumer market through offering extra services and gadgets as a mode of diversification (Lawrence \& Francis, 2009). Given the application of new products and services to existing customers; their needs, wants, and purchasing behaviours are to be contemplated early on in growing new products and services. Contrary, the initial stages for entrepreneurs do not have such stock of information. This research therefore set out to find the effect of customer development strategies on performance of start-up carbon projects with focus on Sustainable Agriculture Tanzania (SAT).

\section{Objectives of the Study}

The general objective of this study is to establish the effect of customer development strategies on performance of start-up carbon projects; a case of study of sustainable agriculture Tanzania (sat).

The research had the following specific objectives:

i. To examine the influence of business model on performance of start-up carbon projects.

i. To examine the influence of customer service systems on performance of start-up carbon projects.

ii. To determine the influence of communication process on performance of start-up carbon projects.

iii. To establish the influence of competitive pricing strategies on performance of start-up carbon projects.

\section{Theoretical Review}

This research was guided by the theory of product market fit and cue utilization theory.

\subsection{Theory of Product Market Fit}

Andreesen (2007) asserts that great variation in accomplishment, competition and diversity is observed in the broad range of start-ups. He mentions that teams, products and markets are core concepts that need to be examined in order to effectively understand product/market fit. Product/Market fit begins by using customer lifecycle conversion metrics namely; activation and retention. These two key metrics make up the value metrics however keeping customers coming is the ultimate validation as when it comes to making payments on purchases this may have been done by another party (Maurya, 2012). In conclusion, profits result from acquiring the Product/Market fit. Maurya, (2012) commends use of an iteration framework to determine 
International Journal of Business Management, Entrepreneurship and Innovation, Volume 3, Issue 1, 2021, PP 49-64, ISSN 2707-8027

[ICAB

Product/Market fit. One metric for determining product/market fit is if at least forty percent of surveyed customers show that they would be "very disappointed" if they do not have access to the product or service. Sean Ellis is noted to have familiarized this approach after examining many start-ups. Raul Vohra of Superhuman has initiated a survey-based model based on the forty percent rule to assist post-launch start-ups test and optimize this metric. This theory will therefore enable the researcher and also provide an understanding on how product and price influence the business model thereby helping improve its performance.

\subsection{Cue Utilization Theory}

Easterbrook's cue utilization theory was developed to collect information on how various cues form perceptions. The theory suggests that products and services are composed of several cues that indicate product or service quality. Proposing that cues are brought about by two different states of predictive and confidence values. Predictive value involves a customer's ability to determine product quality by observing its cues whilst the confidence value is determinant on the customer's ability to use and judge cues differently. A study carried out by Nazlida Muhamad \& Vai Leong (2013) on the measurement of perceived quality on Asian brands of cars found that customers not only perceive quality as branding, but maintenance costs among other features as determinants of quality. After sales support was also identified as an aspect of quality. Predictive and confidence values are further broken into intrinsic and extrinsic cues. Intrinsic cues inform on physical characteristics of products or services whilst extrinsic cues assist customers in determining quality as they inform on brand and pricing. Product familiarity is found to relate to cue utilization in product evaluation. It was generally inferred that, when price is the only cue, customers value the higher cost product (Tull, Boring and Gonsior, 1964; McConnell, 1968). However, when associated with other cues, analysis ensues (Andrews \& Valenzi 1970; Jacoby, Olson and Haddock, 1971). The cue utilization theory will be used to find the impact of competitive pricing on performance.

\section{Empirical Review}

Assessment was based on prior research performed on customer attributes, product needs, and the price needs.

\subsection{Business Model}

In the value proposition canvas, price and product attributes play a key role in testing customer satisfaction. Pricing in the business model reflects on how businesses make and save money while the product attributes is most relevant to solving consumer problems. Kotler and Armstrong (2010) define a product as whatever is offered to the market to satisfy the consumers. "They are all attributes that can influence customer choice," (Mohammad, Wang and Sunayya, 2012). Analyses support the effect of product influences on a company's performance (Kazem and Heijden, 2006). It is therefore required of the firm to have the initiative and effective plan to consistently meet and surpass the value they create for its customers, (Cavusgil and Zou, 2009). All inclusive, studies by Albaum Johnson, and McCullough, (2007) found that the representation of a product and its style has a positive influence on firm performance. Other research carried out in international markets on association of product brilliance and company potential found a positive correlation, (Terpstra and Sarathy, 2007). Businesses that offer highquality products/services increase the value associated with customer performance. Research studies conducted in Europe also show the beneficial influence and correlation of a product's quality on sales performance.

According to Leonidou, Hult, and Thomas, (2002) increasing sales performance can be achieved through product adaptation (spreading administrative and export costs over a number of products) and serving multiple customer markets and segments, (Beamish and Munro, 2009). 
International Journal of Business Management, Entrepreneurship and Innovation, Volume 3, Issue 1, 2021, PP 49-64, ISSN 2707-8027

iJCAB

Exports however provide a narrow range in products as compared to domestic markets due to a number of challenges including high costs of operation connected to international operations, (Albaum Johnson \& McCullough, 2007). Price is the charge as a result of processing, marketing and availing a product, (Kotler, 2007). On the other hand, Zeithaml (2008) views price as a cue that influences consumer views on product value. Price is also viewed as the real or estimated worth of a product (Kotler et al., 2003). There is identified correlation between price, and company performance (Colpan, 2006; Dooleet et al., 2006; Owomoyela et al., 2013). This shows how it plays a significant role in product/service marketability.

\subsection{Customer Service Systems}

Customer Service Systems serve as technological and organizational networks that assist in service provision and satisfying customer needs. Jorge (2015) views service systems as a composition of elements such as people, tools, facilities and computer programs that have structure, behaviour and a purpose or goal. Technology is deeply rooted in user experience. According to studies done in the service industry, the intent behind experience design has been to generate captivating customer experience on every aspect of customer interaction. It affects both customer interactions and future behaviour. During the analysis of the impacts of technology it was found that implementing strategies that foster technology and its innovation have stirred companies to attract new customers (Zahra, 1996; Zahra \& Bogner, 2000; Cooper, 2000; Sofuoglu et al. 2007; Liu \& Tsai, 2007). However, technological development does not ascertain success without satisfactory communication and cooperation. Internal cooperation and teamwork within the organization is also needed. Huawei has developed rapidly in the high tech sectors such as telecommunications, intelligence, IT equipment and solutions. Serving regions worldwide, it insists on creating value for customers. Lenovo is also known for highly innovative technology. In China, its range of extensive products has met the diverse needs of users leading to Lenovo being ranked as the first for eight consecutive years. Huawei and Lenovo have been leading in the speed of product development and market response. As per encoded data, customer knowledge management has played a significant role in identifying customer needs and design optimization.

\subsection{Communications Process}

Communication is a delivery of information amongst people, that is understood and acted upon (Obamiro, 2008). It is very central to human activity and thus the basis of everything. In organizations, communication involves a structure of networks that link administrators to staff (internal) and external communication disseminated to customers, suppliers and creditors (external). Several studies emphasize on the impact of communication on performance (Garnelt, Marlowe \& Pandley, 2008; Pandley \& Garnelt, 2006). Oyetunde \& Oladejo, (2012) in "a study of communication approach and firm performance appraisal of Nigerian bottling company; Coca Cola" validated the relationship between communication and efficiency in performance. They also suggested a need for improvement if management embraces proper communication. Kukule (2012) on his research on internal communication points to the need for employee communication. According to research done on 100 manufacturing companies in Nigeria on the influence of business communication practices, the findings determined that, the proportionality of companies incorporating productive work communications affects performance on; sales, satisfaction, quality of goods and services. Ebarefimia, Ahmed, Ganiyat \& Rashdidat (2012).

\subsection{Competitive Pricing Strategy}

Competitive pricing involves choosing relevant price points to take advantage of what competitors offer. Price is one of the fundamental components when it comes to creating 
International Journal of Business Management, Entrepreneurship and Innovation, Volume 3, Issue 1, 2021, PP 49-64, ISSN 2707-8027

\section{[IJCAB}

marketing strategies. It is one of the cues that consumers notice first and one of the deciding factors when it comes to purchase. Recent studies (Canina \& Enz, 2008) concerning competitive pricing centred on price changes between various hotels in the United States and their competitors. The comprehensive study indicated higher gains for higher pricing as opposed to discounting to undercut competitors. A study done on the differences of offers from a large German automobile manufacturer tested perceived customer satisfaction as a result of price bundling. In all cases, prior owners seeking for a substitution were approached and asked to evaluate an offer. The offers were differentiated among three levels of price bundling. The findings of the research indicated that among price discount conditions, the pattern related to satisfaction, likelihood of recommending and likelihood of repurchasing variables; the completely de-bundled price discounts indicated higher evaluations (Johnson, Herrmann \& Bauer, 1999).

\section{Conceptual Framework}

\section{Independent Variables}

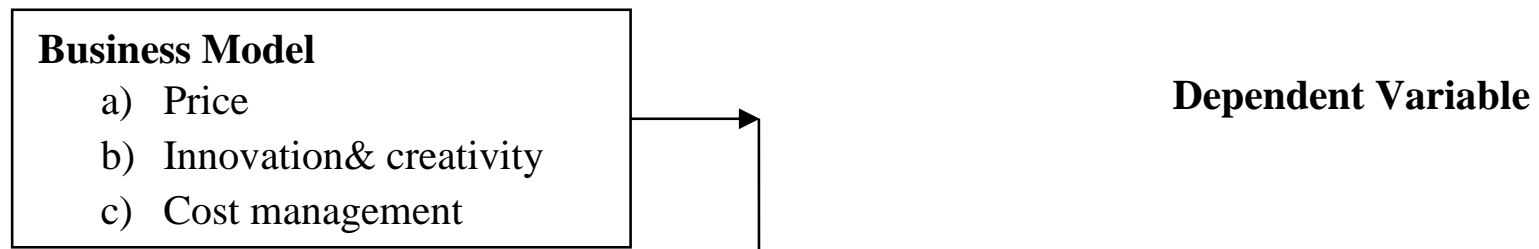

\section{Customer Service systems}

a) Accessibility \& availability

b) Flexibility

c) Reliability \& response time

d) System integration

e) Multi-project capability

f) Querying ease

g) Technology

\section{Communication Process}

a) Planning

b) Reduced time

c) Task \& schedule slippage

d) Project view

\section{Competitive Pricing Strategy}

a) Premium pricing

b) Discounts

Figure 2.1: Conceptual Framework

\section{Researcher (2021)}

\section{Research Methodology}

Survey methodology was applied for the research. The population of the study was 200 being 167 individual customers and 33 companies and organizations. Individual customers were 
International Journal of Business Management, Entrepreneurship and Innovation, Volume 3, Issue 1, 2021, PP 49-64, ISSN 2707-8027

\section{[IJCAB}

drawn from the current connections developed by Sustainable Agriculture Tanzania. The applied method for extrapolating a representative sample was stratified random sampling method in view of its homogeneity. Since selected groups of study are huge and there is a limit of time and resource, a minimum of $30 \%$ sampling is proposed by Mugenda \& Mugenda (2003). The study consequently used 60 respondents drawing 10 companies plus organizations and 50 individual customers. The respondents of the companies consisted of the CEO or any one senior manager conversant and other members with details of their respective organization inclusive of customers. The reason for picking three people per organization is because of the small population of companies, twenty-one companies involved. The study also sampled 50 individual customers and therefore the total sampled size was 60 .

Data collection was done through questionnaires with both structured and unstructured questions utilised in collecting primary data. It contained questions relating to the carbon markets for organizations in the start-up carbon projects. The questionnaire also had likert scales of 1 to 5 to gauge the perception of the respondents regarding the issues they were being interviewed on. The questionnaire was administered mainly by the researcher and her assistant then collected later. The primary data submitted by questionnaires was analyzed on excel to find out existing correlation. Multivariate regression was employed to ascertain if a collection of variables forecast a stated dependent variable. Mugenda and Mugenda, (2003) recorded numerous efforts to ascertain whether a collection of variables forecast a specified dependent variable.

\section{Data Analysis Results}

Inferential statistics were given using correlation coefficient, coefficient of determination (RSquare), analysis of variance as well as regression coefficients. Test for autocorrelation was also conducted.

Table 1: Correlation Coefficients for Variables Relationship

\begin{tabular}{lcccc}
\hline & $\begin{array}{c}\text { Business } \\
\text { model }\end{array}$ & $\begin{array}{c}\text { Customer } \\
\text { service } \\
\text { systems }\end{array}$ & $\begin{array}{c}\text { Communicati } \\
\text { on process }\end{array}$ & $\begin{array}{c}\text { Competitive pricing } \\
\text { strategy }\end{array}$ \\
\hline $\begin{array}{l}\text { Business model } \\
\begin{array}{l}\text { Customer service } \\
\text { systems }\end{array}\end{array}$ & 1 & 0.467 & 0.467 & 0.467 \\
$\begin{array}{l}\text { Communication } \\
\text { process }\end{array}$ & 0.467 & 1 & 0.655 & 0.772 \\
$\begin{array}{l}\text { Competitive pricing } \\
\text { strategy }\end{array}$ & 0.509 & 0.655 & 1 & 0.677 \\
\hline
\end{tabular}

Survey data (2020)

The highest correlation was found between customer service systems and competitive pricing strategy with a correlation coefficient of 0.772 . Other major correlations were between communication process and competitive pricing strategy (0.677), communication process and customer service systems $(0.655)$ as well as business model and communication process.

Table 2: Coefficient of Determination $\left(\mathbf{R}^{2}\right)$

$$
\text { Change Statistics }
$$

\begin{tabular}{cccccccccc}
$\mathrm{R}$ & $\mathrm{R}^{2}$ & $\begin{array}{c}\text { Adjusted } \\
\mathrm{R}^{2}\end{array}$ & $\begin{array}{c}\text { Std. Error of } \\
\text { the Estimate }\end{array}$ & $\mathrm{R}^{2}$ Change & $\begin{array}{c}\mathrm{F} \\
\text { Change }\end{array}$ & df1 & df2 & $\begin{array}{c}\text { Sig. F } \\
\text { Change }\end{array}$ & $\begin{array}{c}\text { Durbin- } \\
\text { Watson }\end{array}$ \\
\hline .852 & .726 & .702 & .14601 & .726 & 30.402 & 4 & 46 & .000 & 1.970 \\
\hline
\end{tabular}

Survey data (2020) 
International Journal of Business Management, Entrepreneurship and Innovation, Volume 3, Issue 1, 2021, PP 49-64, ISSN 2707-8027

\section{IJCAB}

Results in Table 2 show a significant prediction given that $p$-Value $=0.000<0.05$ when df $1=4$ and df2 46 at 5\% significant level. The researcher tested for autocorrelation using Durbin Watson statistic.

Normality is gauged at values of 1.5-2.5. Interest begins to show for those values under 1 or above 3," (Field,2009). According to this study, Durbin Watson statistic was 1.970 which falls within the relatively-normal range and therefore there was no indication of autocorrelation in the residuals from a regression analysis.

Table 3: Analysis of Variance (ANOVA)

\begin{tabular}{lccccc}
\hline & Sum of & \multicolumn{4}{c}{ Mean } \\
& Squares & Df & Square & F & Sig. \\
\hline Regression & 2.593 & 4 & .648 & 30.402 & .000 \\
Residual & .981 & 46 & .021 & & \\
Total & 3.573 & 50 & & & \\
\hline
\end{tabular}

a. Predictors: (Constant), business model, customer service systems, communication process, competitive pricing strategy

b. Dependent Variable: Performance of Forest Carbon Projects

\section{Survey data (2020)}

As shown in Table 3, F-Calculated $(4,46)=30.402>$ F-Critical $(4,46)=2.758$ at 2-tail test and $95 \%$ confidence level. Results also show p-Value $=0.000<0.05$. It corroborates at composite level, the predictors (business model, customer service systems, communication process, and competitive pricing strategy) significantly influence performance of forest carbon projects.

Table 4: Regression Coefficients

\begin{tabular}{lccccc}
\hline & Unstandardized Coefficients & \multicolumn{4}{c}{ Standardized Coefficients } \\
& $\mathrm{B}$ & Std. Error & Beta & $\mathrm{t}$ & Sig. \\
\hline (Constant) & .681 & .240 & & 2.841 & .007 \\
Business Model & .180 & .067 & .254 & 2.707 & .009 \\
Customer Service System & .210 & .068 & .379 & 3.105 & .003 \\
Communication Process & .306 & .077 & .336 & 3.963 & .000 \\
Competitive Pricing Strategy & .076 & .049 & .180 & 1.541 & .030 \\
\hline
\end{tabular}

a. Dependent Variable: Performance of forest carbon projects

\section{Survey data (2020)}

Findings as shown in Table 4 express that, when business model, customer service systems, communication process, and competitive pricing strategy are individually increased by one unit, performance of forest carbon projects would increase by $0.180,0.210,0.306$, and 0.076 units respectively. The opposite is also true. When all the explanatory variables are held constant, performance of forest carbon projects will remain at 0.681 out of 5 scores. This indicates that business model, customer service systems, communication process, and competitive pricing strategy all significantly influence performance of forest carbon projects given $\mathrm{p}-\mathrm{V}$ alue $<0.05$ for each. R-Square of 0.726 with the standard error of estimate being 0.146 . This implies that collectively, business model, customer service systems, communication process, and competitive pricing strategy explain changed performance of forest carbon projects up to 72.6 percent. This can be summarized by the following model: $Y=0.681+0.180 X_{1}+210 X_{2}+$ $0.306 X_{3}+0.076 X_{4}$ where $\mathrm{Y}=$ performance of forest carbon projects and $\mathrm{X}_{i}$ are the explanatory variables.

The findings are in line with Blank and Dorf (2012) argument that; for desired performance to be achieved, there is need for an effective, contemporary and customer-centric development 
International Journal of Business Management, Entrepreneurship and Innovation, Volume 3, Issue 1, 2021, PP 49-64, ISSN 2707-8027

iJCAB

strategy that primarily needs a repetitive process of 'building and evaluating' products. Evidently, agile procedures target efficiency-based approaches rather than promotion of product enhancement thinking (Bosch et al., 2013). This can easily be achieved through value creation using various methods utilized by a company to create benefits in the chain including creation of value, distribution and development of complementary assets and market strategies, (Chesbrough, 2009).

\section{Conclusions}

In conclusion, customer development strategies in start-up forest carbon projects are important for performance. Contributing to this performance are particularly the company's prices, enhanced innovation and creativity, business management system, reduction of the time required for decision-making, and improved planning of activities. At the same time, use of IT data management systems has to a large extent made the decision-making process faster. These aspects generally lead to better management of budgets, efficiency in service provision, consistent increase in revenue and increased number of customers. Moreover, customer development strategies lead to improvement in customer satisfaction. The highest correlation was found between customer service systems and competitive pricing strategy with a correlation coefficient of 0.772 . Other major correlations were between communication process and competitive pricing strategy (0.677), communication process and customer service systems $(0.655)$ as well as business model and communication process.

\section{Recommendations}

The researcher gives the following recommendations: Start-up carbon projects should be keen on employing business models that are effective in their relationships and that allow expression of a company's logic for earning money. Customer service systems are key in ensuring that customers are served with diligence and their requirements managed effectively. Organizations and especially those in start-up carbon projects should ensure they install relevant and effective customer service systems. Organizations should adopt a sustainable pricing strategy that would give start-up carbon projects a competitive edge plus promote customer growth and satisfaction. Use of IT data management systems has to a large extent made decision-making processes faster. These aspects generally lead to; better management of budgets, efficiency in service provision, consistent increase in revenue and increased number of customers. Moreover, customer development strategies lead to improvement in customer satisfaction.

\section{REFERENCES}

Achleitner, A.-K., 2013. Start-up unternehmen. Gabler Wirtschaftslexikon, p.Vers.7.

Adler, C. 2011. Ideas are overrated: startup guru Eric Ries' radical new theory. Wired. Retrievedon 28.9.2017 https://www.wired.com/2011/08/st_qareis

American Heritage Dictionary. 2017. Startup. Retrieved on 15.5.2017 https://ahdictionary.com/word/search.html?q=startup

Andreesen, M. 2007. Product/Market Fit. Stanford University. Retrieved on 30.5.2017 http://web.stanford.edu/class/ee204/ProductMarketFit.html

Andrews, I.R \& Valenzi, E.R., (1970). " The Relationship Between Price and Blind-Rated Quality for Margarines and Butter,” Journal of Marketing Research. 393-395.

Armstrong, G. \& Kotler, P.1999. Marketing: An introduction. 5 th edition. United States. Prentice hall.

Aspara, J., Lamberg, J., Lakukia, A. \& Tikkanen, H. (2011). Strategic management of business model transformation: lessons from Nokia.

Barney, J.B. (2008). Gaining and sustaining competitive advantage. New York: AddisonWesley. 
International Journal of Business Management, Entrepreneurship and Innovation, Volume 3, Issue 1, 2021, PP 49-64, ISSN 2707-8027

[ICAB

Bhide, A. 1994. How entrepreneurs craft strategies that work. Harvard Business Review. Vol. 72, No 2, 150-161.Blank, S. 2013. Why the lean start-up changes everything. Harvard Business Review. Vol. 91,No 5, 63-72.

Bhide, A. 2000. The Origin of Evolution of New Businesses. Oxford University Press Inc.

Blank, S. \& Dorf, B. (2012). The Startup Owner's Manual. The Step-by-Step Guide for Building a Great Company. Pescadero: K\&S Ranch Publishers.

Blank, SA. 2005. The four steps to the epiphany: Successful Strategies for Products that Win CafePress. com.

Blank, S. (2017). The Lean Canvas: Your startup blueprint. Blankcanvas. Retrieved on 16.11.2017 https://www.blankcanvas.io/canvases/lean-canvas

Blank-Dorf (2012). Blank, Steve; Dorf, Bob: The Startup's Owner Manual: the Step-by-Step Guide for Building a Great Company, 1st edition, K\&S Ranch Press, Pescadero CA, 2012

Bond, P., 2012. Emissions Trading, New Enclosures and Eco-Social Contestation. Antipode, 44(3), pp.684-701.

Bosch, Jan, Olsson, H.H., Bjork, J. \& Lujngblad, J., (2013). "The early stage software start-up development model: a framework for operationalizing lean principles in software startups.” In Lean Enterprise Software and Systems, Volume167, 1-15.

De Vellis; RF (2003), Relationship between degree of risk, cost and level of compliance to occupational health and safety regulations in construction., British Medical Journal, $314,572$.

Bumpus, A.G., (2011). The Matter of Carbon: Understanding the Materiality of tCO2e in Carbon Offsets. Antipode, 43(3), pp.612-638.

Canina, L., \& Enz. A.C., (2008). Pricing for revenue enhancement in Asia and Pacific Region hotels: A study of relative pricing strategies. Cornell Hospitality report, 8(3), 2842.http://www.hotelschool.cornell.edu/research/chr/pubs/reports/2008.html

Carayannis, E. G. \& Alexander, J. (2002). Is technological learning a firm core competence, when, how and why? A longitudinal, multi-industry study of firm technological learning and market performance. Technovation. Vol. 22, No. 10, 625-643.

Chesbrough, H. \& Rosenbloom, R.S. (2002). "The role of business model in capturing value from innovation. Evidence from Xerox Corporation's technology spin-off companies", Industrial and Corporate Change. Vol.11, No.3, pp.529-555.

Chesbrough, H. (2010). Business model innovation: opportunities and barriers.

Chiliya .N, Herbst.G, and Roberts- Combard.M (2009). The impact of marketing stratefieson profitability of small grocery shops in South African Townships. African Journal of Business Management 3 (3), 70 - 79.

Christensen, C.M. (1997). The Innovators Dilemma. When New Technologies Cause Great Firmsto Fail. Boston: Harvard Business School Press.Christensen, C. M. \& Rosenbloom, R. S. 1995. E

Christensen, W.G., Johansson, D.J. \&Perona, J.A. (2009). Pricing related performance. International Journal of fundamental Psychology and social sciences, 1(2): 26-34

Clauss, T. (2016). Measuring business model innovation: Conceptualization, scale development and proof of performance. R\& D Management, 47(3), 1-19.

Cooper, R.G., (2000). Product innovation and technology strategy. Res. Technol. Manage., 43:38-41.

Colpan, A.M. (2006). Dynamic effects of product diversity, international scope and Keiretsu membership on the performance of Japan's textile firms in the 1990s. Asian Business and Management, 5(3), 419-445. 
International Journal of Business Management, Entrepreneurship and Innovation, Volume 3, Issue 1, 2021, PP 49-64, ISSN 2707-8027

[IJCAB

Crowne, M., (2002). Why software product startups fail and what to do about it. Evolution of software product development in startup companies. Paper, DOI 10.1109/IEMC.2002.1038454. Source: IEEEXplore

Csikszentmihalyi, M. (2000), "The costs and benefits of consuming", Journal of Consumer Research, Vol. 27 No.2, pp. 267-72.

Dalsgaard, S., 2014. Carbon Value between Equivalence and Differentiation. Environment and Society: Advances in Research, 5(1), pp.86-102.

Day, G. and R. Wensley, (2010). Assessing Advantage: A Framework for Diagnosing Competitive Superiority. Journal of Marketing, 52: 1-20.

Demil \& Lecocq, X., (2010). "Business model evolution: in search of dynamic consistency," Long Range Planning, Vol. 43, No.2, pp.227-246.

Dirk Schneckenberg, Vivek K. Velamuri \& Christian Comberg, (2017). Business model innovation and decision making: Uncovering mechanisms for coping with uncertainity. R\&D Management 47(3):404-419.

Doole, I.,Grimes, T., \& Demack, S. (2006). An exploration of the management practices and processesmost closely associated with high levels of export capability in SEMs.

Doz, Y.L., \& Kosonen, M. (2010). Embedding Strategic Agility: A Leadership Agenda for Accelerating Business Model Renewal. https://doi.org/10.1016/j.lrp.2009.07.006

Durbin, J.; Watson, G.S. (1950). “Testing for Serial Correlation in Least Squares Regression, I." Biometrika. 37 (3-4): 409-428.

Durbin, J.; Watson, G.S. (1951). "Testing for Serial Correlation in Least Squares Regression, II.” Biometrika. 38 (1-2): 159-179.

Ebarefimia, E., Ahmed, O.K., Ganiyat, A.O. \& Rashdidat, K., (2012). Impact of Business Communication on Organizational Performance in Nigerian Companies. Australian Journal of Business and Management Research, Vol.2.No.01,16-26

Eisenmann, Thomas, R., Ries, E, \& Dillard, S., (2012). "Hypothesis -driven entrepreneurship: The lean startup." Harvard Business School Entrepreneurial Management Case, Case No. 812-095. Available at SSRN: hhtp://ssrn.com/abstract=2037237

Elsworth, R., Worthington, B. \& Morris, D., (2012). Help or Hindrance? Offsetting in the EU ETS, Sandbag.

Ervine, K., 2014. Diminishing Returns: Carbon Market Crisis and the Future of MarketDependent Climate Change Finance. New Political Economy, 19(5), pp.723-747.

Fredriksen, A. et al., (2014). A conceptual map for the study of value, (LCSV Working Paper Series No. 2). Leverhulme Centre for the Study of Value: University of Manchester.

Garnett, J.L.,Marlowe, J. \& Pandey, S.K., (2008). Penetrating the performance predicament: communication as a mediator or moderator of organizational culture's impact on public organizational performance. Wiley online library, https://doi.org/10.1111/j.1540-6210.2007.00861.x

Gharakhani, D., Farrokhi, M., Khajevand, A., and Farahmandian, A. (2014). Customer's Attributes and Organizational Performance. American Journal of Industrial Engineering. 2014, 2(1), 1-4

Giachetti, C., \& Marchi, G. (2010). Evolution of firms' product strategy over the life cycle of technology-based industries: A case study of the global mobile phone industry, 19802009. Business History, 52(7), 1123-1150.

Goldman, M., (2010). Kuyasa CDM Project: Renewable energy efficient technology for the poor, Washington D.C.: United Nations Development Programme. Available at: http://www.growinginclusivemarkets.org/media/cases/SouthAfrica_Kuyasa_2010.pdf [Accessed September 23, 2016]. 
International Journal of Business Management, Entrepreneurship and Innovation, Volume 3, Issue 1, 2021, PP 49-64, ISSN 2707-8027

[ICAB

Harb, Abdo, Y., Noteboom, C. and Sarnikar, S., (2015). "Evaluating Project Characteristics for Selecting the Best-fit Agile Software Development Methodology: A Teaching Case." Journal of the Midwest Association for Information Systems (JMWAIS) 1(3):33-51.

Harker, J., Taylor, P. \& Knight-Lenihan, S., (2016). [Pre-print] Multi-level governance and climate change mitigation in New Zealand: lost opportunities. Climate Policy. [Online] Available at: http://www.tandfonline.com/doi/full/10.1080/14693062.2015.1122567 [Accessed September 23, 2016].

Hinterhuber, A., (2004). Towards value-based pricing- an integrative framework for decision making. Industrial Marketing Management, 33(8), 765-778.

Jacoby, J., Olson, M.C. \& Haddock, R.A., (1971). "Price, Brand Name and Product Composition Characteristics as Determinants of Perceived Quality," Journal of Applied Psychology. 55, 570-579.

Johnson, M.D., Herrmann, A., \& Bauer, H.H. (1999). The effects of price bundling on consumer evaluations of product offerings. International Journal of Research in Marketing, 16(2), 129-142. doi: 10.1016/S0167-8116(99)00004-X.

Johnson, J.T., Busbin, J.W., \& DeConinck, J. (2008). The evolution of sustainable competitive advantage: from value chain to modular outsource networking.

Jorge, C., Hansjorg, F., Stefan, N., Gerhard, S., Rudi, S., \& Christof, W., (2015). Fundamentals of Service Systems. Service Science: Research and Innovations in the Service Economy ( $1^{\text {st }}$ ed.). Springer.

Kathryn W., Nicholas, W., and Sandra, H. S. (2008). International Journal of Entrepreneurial Behaviour \& Research 4(3):217-238

Kazem, A. \& Heijden, B.V.D. (2006). Exporting firms "strategic choices: the case of Egyptian SEMs in the food industry, S.A.M. Advanced Management Journal, 71(3),21-33.

Kemppainen, K., Vepsalainen, A.P.J., \& Tinnila, M. (2008). Mapping the structural properties of production process and product mix. International Journal of Production Economics, 111(2), 713-728.

Kjellberg, H. \& Mallard, A., 2013. Valuation Studies? Our Collective Two Cents. Valuation Studies, 1(1), pp.11-30.

Knox-Hayes, J. \& Hayes, J., 2014. Technocratic norms, political culture and climate change governance. Geografiska Annaler: Series B, Human Geography, 96(3), pp.261-276.

Kothari, S.P, Chan W.S \& Frankel, R. (2004). Testing behavioural finance theories using trends and consistency in financial performance.

Kotler, P. \& Armstrong, G. (2010). Principles of Marketing, 13 ed, New Jersey, Pearson Prentice Hall.

Kotler, P., Ang, S.H., Leong, S.M., Tan, T.C. (2003), Marketing Management: An Asian Perspective Singapore: Pearson Education Asia.

Kossoy, A. et al., (2015). State and Trends of Carbon Pricing 2015, Washington D.C.: World Bank.

Kukule, I. (2012). Internal communication crisis and its impact on organization's performance. Caucasian Economic Triangle, 2.2012 ISSN: 2233-3231.

Lansing, D.M., (2011). Realizing Carbon's Value: Discourse and Calculation in the Production of Carbon Forestry Offsets in Costa Rica. Antipode, 43(3), pp.731-753.

Lawrence Ang \& Francis Arthur B., (2009). Customer development strategies for exceeding expectations- An explanatory study.

Layfield, D., (2013). Turning carbon into gold: the financialisation of international climate policy. Environmental Politics, 22(6), pp.901-917.

Leonidou, L.C, Morgan, N.A. \& Hult, G.M.T. (2016). “Assessing performance outcomes in marketing." 
International Journal of Business Management, Entrepreneurship and Innovation, Volume 3, Issue 1, 2021, PP 49-64, ISSN 2707-8027

[ICAB

Liozu, S.M., (2013). Pricing capabilities and firm performance: A socio-technical framework for the adoption of pricing and transformational innovation. (Electronic Thesis or Dissertation). Retrieved from https://etd.ohiolink.edu/

Liu, P.L. \& Tsai, C.H., (2007). The influence of innovation management and new product development performance in Taiwan's Hi-tech industries. Res. Journal of Business Management, 1:20-29.

Lohmann, L., (2014). An alternative to "Alternatives." World Rainforest Movement Bulletin, (209). Available at: http://wrm.org.uy/bulletins/issue-209/ [Accessed September 23, 2016].

Louis, A., (1964). An Introduction to Organizational Communication.

Mathieu, V.A. (2001). Service strategies within the manufacturing sector: benefits, costs and partnership. The International Journal of Service Industry Management, Vol. 12, No.5, (pp.451-475).

Maurya, A.(2012). Running Lean- Iterate from Plan A to a Plan that Works. USA: O'Reilly Media, Inc. ISBN: 978-1-449-30517-8.

McCarthy, J. \& Wright, P. (2004), Technology as Experience, The MIT Press, Cambridge, MA.

McConnell, J. (1968). The Price-Quality Relationship in an Experimental Setting. Research Article https://doi.org/10.1177/002224376800500309

Mistry K., Jaggers J., Lodge A., Alton M., Mericle J., Frush K., \& Meliones J., (2008). Using six sigma methodology to improve handoff communication in high risk patients. Advances in Patient Safety: New directions and alternative approaches. Vol. 3. Performance and Tools. AHQR Publication No. 08-0034-3 Rockville, M.D: Agency for Healthcare Research and Quality.

Mittal, V., Katrichis, J. M., and Kumar, P. (2001) "Attribute performance and customer satisfaction over time: evidence from two field studies", Journal of Services Marketing, Vol. 15 Issue: $\quad$ 5, https://doi.org/10.1108/EUM0000000005655

Miller, D., (2008). The uses of value. Geoforum, 39(3), pp.1122-1132.

Mohammad A.H, Wang A and Sunayya B (2012). Investigating on Tourists satisfaction: An empirical study on East Lake. European journal of business and management. Vol.4 No.7

Morris, M. (2005). The entrepreneur's business model: toward a unified perspective.

Mugenda, O. M., \& Mugenda, A. G. (2003). Research methods: Qualitative and Quantitative Approaches. Nairobi: Acts Press. Mugenda, O. M., \& Mugenda, A. G. (1999). Research methods: Qualitative and Quantitative Approaches. Nairobi: Acts Press.

Mullins, J. \& Komisar, R., (2009). Getting to Plan B: Breaking Through to a Better Business Model.

New Zealand Environmental Protection Authority, 2014. NZ ETS 2014 - Facts and Figures, Wellington.

Newell, P. \& Paterson, M., 2010. Climate Capitalism, Cambridge: Cambridge University Press.

Nobel, Carmen. (2013). “ Teaching a 'Lean Startup Strategy.” Harvard Business School.

Njihia, M. Super Ongea Tariff - the tariff where the price moves, Michael Joseph does the service intro.2009. Available on http://www.mbuguanjihia.com

Obamiro, J.K., (2011). Management Principles and Strategies, Lagos: Pumak Nigeria Limited.

Ogunmokun, G.O., \& Esther, L.L. (2004). Product development process and performance of export ventures: a study of exporting companies in the People's Republic of China. Journal of Asian Pacific Marketing, 3(2), 83-98.

Okkutah, M., Safaricom Launches New Tariff to Stabilise Prices, 2010, Available on http://www.businessdailyafrica.com 
International Journal of Business Management, Entrepreneurship and Innovation, Volume 3, Issue 1, 2021, PP 49-64, ISSN 2707-8027

[ICAB

Okumu, K. \& Roper, C. (2013). Strategic Management Practices in Mbagathi District Hospital, Nairobi, Kenya: Unpublished MBA thesis: University of Nairobi

Olwig, M.F. et al., 2015. Inverting the moral economy: the case of land acquisitions for forest plantations in Tanzania. Third World Quarterly, 36(12), pp.2316-2336.

Osterwalder-Pigneur (2010). Osterwalder, Alex; Pigneur, Yves: Business Model Generation, 1st edition, J. Wiley \& Sons, Hoboken, NJ, 2010

Owomoyela, S.K., Oyeniyi, K.O. \& Ola, O.S., (2013).Investigating the impact of marketing mix elements on consumer loyalty: An empirical study on Nigerian Breweries Plc. Interdisciplinary Journal of Contemporary Research in Business. 4(11), 485-496.

Oyetunde, O. \& Oladejo, M., (2012). Communication Approach and Firms Performance: Appraisal of Nigerian Bottling Company (Coca cola), Ilorin- Nigeria. Research on Humanities and Social Sciences ISSN 2224-5766 (Paper) ISSN 2225-0484 (Online) Vol.2, No.1, 2012.

Paterson, M., (2014). Commodification. In C. Death, ed. Critical Environmental Politics. Abingdon: Routledge, pp. 53-62.

Pandey, S.K. \& Garnett, J.L (2006). Exploring Public Sector Communication Performance: Testing a Model and Drawing Implications. Wiley online library, https://doi.org/10.1111/j.1540-6210.2006.00554.x

Prahalad (2010). Impact of Sales Promotion on When, What, and How Much to Buy, in Journal of Marketing Research, Vol.25, pp.342-355.

Prof. Dr. Kollmann, T., Dr. Christoph, S., Linstaedt, J. \& Kensbock, J.(2015). European Startup Monitor p.15

Purdon, M., (2015). Opening the Black Box of Carbon Finance "Additionality": The Political Economy of Carbon Finance Effectiveness across Tanzania, Uganda, and Moldova. World Development, 74(October), pp.462-478.

Ries, E., 2008. The Lean Startup: How Today's Entrepreneurs Use Continuous Innovation to Create Radically Successful Businesses.

Robert K. and David N. (2001). The Balance Score Card Translating Into Strategy Into Action, Harvard Business School Press, Boston, MA,

Robertson, M., 2012. Measurement and alienation: making a world of ecosystem services. Transactions of the Institute of British Geographers, 37(3), pp.386-401.

Rowe, W., (2001). Effects of job experience; career stage and hierarchy in leadership style.

Russian Federation's Ministry of Culture - Federal Agency for Tourism (2012), available: http://www.russiatourism.ru/en, accessed April 2013.

Sajuyigbe A.S, Ayanleke S.O and Ola O.S (2013). Impact of packaging on organizational sales turnover: a case study of Patterzon Zoconist Cussons (pz) Plc, Nigeria. Interdisciplinary Journal Of Contemporary Research In Business. 4 (11), 497 - 508.

Sandulli, F.D \& Chesbrough, H. (2009). The two sides of open business model.

Shen, W., (2015). Chinese business at the dawn of its domestic emissions trading scheme: incentives and barriers to participation in carbon trading. Climate Policy, 15(3), pp.339354.

Herman Simon, Frank F. Blisten \& Frank Luby (2008). Manage for profit not market share: A guide to greater profits in highly contested markets.

Skjærseth, J. \& Wettestad, J., (2010). Fixing the EU emissions trading system? Understanding the post-2012 changes. Global Environmental Politics, 10(4), pp.101-123.

Sofuoglu, E., Basoglu, N. and Daim, T., (2007). New software product feature identification: An analysis of E-mail user characteristics and functional requirements. Journal of Applied Science., 7:59-65. 
International Journal of Business Management, Entrepreneurship and Innovation, Volume 3, Issue 1, 2021, PP 49-64, ISSN 2707-8027

[ICAB

Solomon, G.T.; Bryant, A.; May, K.; Perry, V. Survival of the fittest: Technical assistance, survival and growth of small businesses and implications for public policy. Technovation 2013, 33,292-301.

Spieth, P., Schneckenberg, D. \& Ricart, J.E. (2014). "Business model innovation-state of the art and future challenges for the field", R\&D Management, Vol.44, No.3, pp. 237-247.

Spash, Clive.(2010). " The Brave New World of Carbon Trading." New Political Economy 15(2): 169-195.

Teece, D. (2012). Business models and dynamic capabilities. Source: https://doi.org/10.1016/j.lrp.2017.06.007

Teece, D.J. (2010). Business models, business strategy and innovation.

Tull, D.S., Boring, R.A. \& Gonsior, M.H. (1964). "A Note on the Relationship of Price and Market-Standing Information on Consumer Brand References.” In R. Hass (ed.), Science, Technology and Marketing. (Chicago: American Marketing Association). 520-531.

Van Riel, A.C.R., Lemmick, J., Streukens, S. and Liljander, V. (2004), “'Boost customer loyalty with online support: the case of mobile telecoms providers", International Journal of Internet Marketing and Advertising, Vol. 1 No. 1, pp. 4-23.

Vai Leong, Nazalida Muhamad \& Sumardi, W.H. (2013). Cue Utilization Theory: A multidimensional measurement on perceived quality of Asian automobile brands.

Whitington, J., (2012). The prey of uncertainty: Climate change as opportunity. Ephemera: Theory \& Politics in Organization, 12(1/2), pp.113-137.

Wirtz, B.W, Pistoia, A., Ullrich, S. \& Gottel, V. (2016). "Business Models: Origin, Development and Future Research Perspectives." Long Range Planning, Vol. 49, No. 1, pp. 36-54.

Wolfe, E.W., Converse, P.D. \& Huang, X. (2008). Response rates for mixed-mode surveys using mail and e-mail/web.

Wright, C. \& Nyberg, D., 2014. Creative self-destruction: corporate responses to climate change as political myths. Environmental Politics, 23(2), pp.205-223.

Yin, R. (2003). Case study research: Design and methods ( $3^{\text {rd }}$ ed.) Thousand Oaks, CA: Sage.

Zahra, S.A., (1996). Technology strategy and financial performance: Examining the moderating role of the firm's competitive environment. J. Bus. Venturing, 11-189-219.

Zahra, S.A. \& Bogner, W.C., (2000). Technology strategy and new venture performance: Examining the moderating role of the firm's competitive environment. J.Bus. Ventur., 15:135-173.

Zeithlam, V.A (2005). Consumer Perceptions of Price Quality and Value. A Means-end Model and Synthesis of Evidence, Journal of Marketing, Vol 52 (July), pp.2

Zott, C., Amit, R. \& Massa, L. (2011). “ The Business Model. Recent Developments and Future Research”, Journal of Management, Vol. 37, No. 4, pp.1019-1042.

This is an open-access article published and distributed under the terms and conditions of the $\Theta \Theta \Theta$ otherwise stated. Access, citation and distribution of this article is allowed with full recognition of the authors and the source. Authors seeking to publish with an Internationally Peer Reviewed Journals should consider https://www.ijcab.org/ by writing to the Editor at editor@ijicab.org or submitting online at https://journals.ijicab.org/journals/index.php. The articles must be quality and meet originality test.

$\frac{\text { IJCAB }}{\text { Publishing Group }}$ 